\section{Psychiatric Social Workers}

In psychiatry more than in any other branch of medicine illness cannot be divorced from its social setting. It is for this reason that psychiatric social workers are playing an increasingly important part in the welfare of the mentally ill. The profession, which had its roots in America, was established in the United Kingdom in 1930 with the formation of the Association of Psychiatric Social Workers. P.S.W.s work mainly in three branches of mental welfarein child guidance clinics, in psychiatric hospitals, and in the community welfare services. ${ }^{1}$

The P.S.W. makes a valuable contribution to psychiatric practice by providing information about the patient's social environment. The patient's relationship with others-relatives, friends, and work-fellows-can contribute to the cause of his mental illness, influence its form and prognosis, and suffer under its impact. Relatives may find it easier to divulge their feelings to the P.S.W. than to the psychiatrist, whose allegiance is to the patient. A home visit, when relatives can be seen en famille, may reveal important conflicts and attitudes which might otherwise be missed in the detached setting of the consulting-room. The P.S.W. is thus well placed to supply the psychiatrist with information which, together with the clinical findings, provides a comprehensive view of the patient at all stages of his illness.

A special province for the P.S.W. is the welfare of those patients who are leaving hospital and returning to live in the community. Relatives, as well as reacting with strong emotions such as guilt and resentment to the illness, may have adapted to it by changing their way of life-a wife may have taken over her husband's responsibilities; an eldest daughter may have cared for her siblings while her mother has been ill. If the patient's stay in hospital has been long his family may have closed their ranks and adapted to life without him. The P.S.W. can prepare for the patient's return home in several ways. She can encourage relatives to dissipate disruptive emotions by creating an atmosphere in which they can be aired without fear of censure. She can try to dispel misconceptions about the illness, and she can point out the problems that will occur. She can use her knowledge of local resources to rehabilitate the patient both socially and at work. When it is not feasible or appropriate for the patient to return home the P.S.W. can look for other suitable accommodation. ${ }^{23}$

During the last decade there has been a move towards providing psychiatric care in the community rather than in institutions such as mental and subnormality hospitals. This policy, embodied in the 1959 Mental Health Act, enables some patients to live with their families and to lead as full a life as possible. Local authorities entrusted by the Act with the responsibility for community care are employing more P.S.W.s. Because of the new policy, general practitioners now have patients suffering from chronic schizophrenia, chronic neuroses, and subnormality, ${ }^{4}$ who in the past would have spent their lives in an institution. General practitioners technically have access to local authority P.S.W.s, but this is still a tentative arrangement in most parts of the country. Experience of closer collaboration between P.S.W.s

1 Jones, K., Brit. F. psychiat. soc. Work, 1967, 9, 61.

2 Post, F., The Clinical Psychiatry of Late Life, 1965, p. 152. Oxford. 3 Kessel, N., and Walton, H., Alcoholism, 1965, p. 128. Harmondsworth Adams, M. (ed.), The Mentally Subnormal. The Social Casework Approach, 1960 . London.

- Davis, N., and Heimler, E., Brit. F. psychiat. soc. Work, 1957, 4. 12.

- Social Work (Scotland) Bill, 1968. H.M.S.O., London. and general practitioners was described by N. Davis and E. Heimler, ${ }^{5}$ who felt that the experimental attachment of a P.S.W. to a general practice for one year had been a worthwhile venture.

The Social Work (Scotland) Bill ${ }^{6}$ recently introduced brings the many aspects of social welfare, including mental welfare, under the supervision of a single department of the local authority. This legislation will enable the P.S.W. to deal more effectively with the whole problem of the mentally ill patient and his dependants. The organization of social work in England and Wales is being studied by the Seebohm Committee, whose findings have not yet been published, but it is possible that the Scottish Bill foreshadows similar changes.

\section{Mite Infestations}

When skin lesions are diagnosed as insect bites the feelings either of anticlimax or of shame which are so often elicited may disguise what is an extremely complex problem. Even in Britain the number of arthropods capable of causing skin irritation in man is very large, ${ }^{1}$ and of these by no means all are insects. Too often no precise diagnosis is achieved. Reactions to these arthropods may be due to irritant substances, but in the majority of cases they are due to the host's allergic reaction to an otherwise harmless substance.

In the case of insect bites the different types of antibody formed often give rise to a well-defined biphasic reaction, an immediate weal within the first hour or two and a delayed response after two days, giving the familiar patterns of " heat bumps" and papular urticaria. Of much greater diagnostic difficulty is the problem of mite infestations. The scabies mite is the only one which is a virtually specific parasite for man. Even in a disease which has been so thoroughly studied $^{2}{ }^{3}$ it is still uncertain how the itching is caused and to what extent it is due to an allergic reaction. That mites can produce powerful antigens is well shown by the recent evidence that they are responsible for some sensitivity reactions to house dust. ${ }^{4}$ The number of adult mites that can be found in burrows in an average case of scabies may be less than a dozen, but the larval forms and males, though unable to produce burrows, cause many of the itchy papules. Other mites are unable to burrow in human skin but may nevertheless similarly be able to cause itchy papules. These mites have a bewildering collection of names and may be derived from sources as diverse as dogs, cats, birds, rodents, and camels, or as an industrial hazard causing such conditions as grain itch and copra itch. Few animals, either domestic or wild, are exempt from mites, and the diagnosis of such infestations in man is fraught with difficulty. The skin lesions may be relatively insignificant-though the itching may be severe - so that there is a temptation for the doctor to dismiss the symptoms as psychosomatic. The unsatisfactory diagnosis of prurigo is the one most likely to cause confusion, but in more florid cases dermatitis herpetiformis may be mimicked. The clinical picture most closely resembles an atypical scabies without burrows. In the present scabies epidemic many such cases will turn out to be scabies.

\footnotetext{
Rook, A. J., Wilkinson, D. S., and Ebling, J., Textbook of Dermatology. 1968. Oxford.

2 Mellanby, K., Scabies, 1943. London.

Heilesen, B., Acta derm.-venereol. (Stockh.), 1946, 26, Suppl. 14.

Maunsell, K., Wraith, D. G., and Cunnington, A. M., Lancet, 1968, $1,1267$.
} 